Tropical Journal of Pharmaceutical Research March 2014; 13 (6): 903-906

ISSN: $1596-5996$ (print); 1596-9827 (electronic)

(C) Pharmacotherapy Group, Faculty of Pharmacy, University of Benin, Benin City, 300001 Nigeria.

All rights reserved.

Available online at http://www.tjpr.org

Original Research Article

http://dx.doi.org/10.4314/tjpr.v13i6.11

\title{
A Prospective Cohort Study of IRS Genes Polymorphisms in Type 2 Diabetes Mellitus Patients during Severe/Acute Hyperglycemia Phase. 2: Association with Glycemic Control
}

\author{
Hasniza Zaman Huri ${ }^{1,2 *}$, Mohd Makmor-Bakry ${ }^{3}$, Rosnani Hashim ${ }^{4}$, Norlaila \\ Mustafa ${ }^{5}$ and Wan Zurinah Wan Ngah $^{6}$ \\ ${ }^{1}$ Department of Pharmacy, Faculty of Medicine, University of Malaya, 50603 Kuala Lumpur, Malaysia, ${ }^{2}$ Clinical Investigation \\ Centre, 13th Floor, Main Tower University of Malaya Medical Centre, 59100 Lembah Pantai, Kuala Lumpur, Malaysia, ${ }^{3}$ Faculty \\ of Pharmacy, Universiti Kebangsaan Malaysia, Kuala Lumpur, Malaysia, ${ }^{4}$ Faculty of Pharmacy, Cyberjaya University College of \\ Medical Sciences Cyberjaya, Malaysia, ${ }^{5}$ Department of Medicine, Faculty of Medicine, Universiti Kebangsaan Malaysia, Kuala \\ Lumpur, Malaysia, ${ }^{6}$ Department of Biochemistry, Faculty of Medicine, Universiti Kebangsaan Malaysia, Kuala Lumpur, \\ Malaysia.
}

*For correspondence: Email: hasnizazh@um.edu.my, hasnizazh@ummc.edu.my; Tel: +603 79676659

\begin{abstract}
Purpose: To investigate the genetic polymorphisms that may contribute to the worsening of glycemic control in type 2 diabetes mellitus (T2DM) with severe or acute hyperglycemia.

Methods: The prospective cohort study included 156 T2DM patients with severe or acute hyperglycemia from all medical wards of the National University of Malaysia Medical Centre (UKMMC) that were treated with insulin therapy. For the genetic association study, we used the polymerase chain reaction-restriction fragment length polymorphism (PCR-RFLP) method. The glycemic control assessment during the acute phase was based on the degree to which the patient achieved the targeted glucose levels. The primary outcome was the influence of IRS gene on glycemic control in T2DM patients with severe/acute phase hyperglycemia.

Results: Insulin Receptor Substrate 1 (IRS1) $(R 2=-0.023, p=0.771)$ and Insulin Receptor Substrate 2 (IRS2) gene polymorphisms $(R 2=-0.160, p=0.046)$ were not associated with glycemic control in T2DM patients with severe/acute hyperglycemia.

Conclusion: The IRS1 and IRS2 genetic factors may not be significant genetic determinant for glycemic control in T2DM patients during severe/acute phase hyperglycemia.
\end{abstract}

Keywords: Insulin receptor substrate, Gene, Polymorphism, Diabetes, Insulin resistance, Hyperglycemia, IRS 1, IRS 2

Tropical Journal of Pharmaceutical Research is indexed by Science Citation Index (SciSearch), Scopus, International Pharmaceutical Abstract, Chemical Abstracts, Embase, Index Copernicus, EBSCO, African Index Medicus, JournalSeek, Journal Citation Reports/Science Edition, Directory of Open Access Journals (DOAJ), African Journal Online, Bioline International, Open-J-Gate and Pharmacy Abstracts

\section{INTRODUCTION}

Primary acute illnesses or diseases are a major threat for hospitalisation in severe or acute hyperglycemic attacks in type 2 diabetes mellitus (T2DM) patients. [1,2]. Thus far, none of the previous studies looked extensively at the possibility that genetic polymorphisms could be a factor influencing glycemic control.

The biggest challenge in dealing with acute and severe hyperglycemia is ensuring that patient glucose levels are at their target level without 
exposing patients to the risks of hyperglycemia and hypoglycemia. Failure to achieve optimum glycemic control during a severe or acute hyperglycemia phase poses a number of risks to patients. Acute hyperglycemia was an independent predictor for increased mortality in the hospital [3].

Nevertheless, neither a single genetic factor nor a combination of genetic factors was previously known to affect significantly glycemic control in T2DM patients with severe/acute hyperglycemia. Insulin Receptor Substrate (IRS) genes mainly Insulin Receptor Substrate 1 (IRS1) and Insulin Receptor Substrate 2 (IRS2) are the most speculated genes to influence the glycemic control based on their key roles to maintain the basic functions of cell growth, survival, and metabolism [4]. Therefore, this study aims to identify IRS 1 and IRS2 gene polymorphisms that could possibly influence the management and treatment of T2DM during severe/acute phase hyperglycemia.

\section{EXPERIMENTAL}

\section{Materials and chemical reagents}

Wizard® Genomic DNA Purification Kit, PCR Master Mix, and 6x blue/orange loading dye were supplied by Promega (Madison, WI, USA). Water (molecular biology grade) was from SigmaAldrich (Irvine, UK). Ethanol, 50 bp DNA ladder, Trizma®, molecular biology grade DMSO, and PCR primers were supplied by Sigma-Aldrich (St. Louis, MO, USA). Low electroendosmosis (EEO) agarose was from Applichem (Darmstadt, Germany). Isopropanol, glacial acetic acid, sodium hydroxide, and EDTA were purchased from Ajax Pty Ltd (Auckland, New Zealand), and 10x NEBuffer solution and restriction enzymes (BstNI, Haell) were from Promega and New England Biolabs (Hitchin, UK).

\section{Apparatus}

Centrifuge (Eppendorf, Hamburg, Germany), Water bath (Memmert, Schwabach, Germany), UV-160A spectrophotometer (Shimadzu, Kyoto, Japan), PTC-100TM thermocycler (MJ Research Inc., Watertown, MA, USA), Fluorchem FC2 gel documentation system (Alpha Innotech, Multimage $^{\mathrm{TM}}$, USA), were used in this study.

\section{Patient recruitment}

This was a prospective study carried out in the medical wards in which 156 patients at National University of Malaysia (UKMMC) were recruited as earlier described [5]. For genetic study, SNP and its association with glycemic control in T2DM patients with severe/acute phase hyperglycemia were studied.

\section{Glycemic control assessment}

Glycemic control assessment was as earlier described [6].

\section{Genetic study}

Genetic study was conducted based on methods as earlier described [5].

\section{Data analysis}

Data collected for each patient were classified by the specific allele, genotype, and haplotype. Fisher's exact test and $x^{2}$ tests were used for nominal data. Spearman's correlation was used for association of gene polymorphisms with glycemic control. HWE test was used as a measure of quality control for genotyping methods $[7,8]$. A $p$-value $>0.05$ indicates that the observed distribution of genotypes was consistent with the HWE assumption. This situation also proves that the results of the PCRRFLP method are applicable.

\section{RESULTS}

\section{Association between variants of IRS1 and IRS2 genes}

Table 1 shows the relationship between gene variants of IRS1 and IRS2. The $x^{2}$ and Spearman's rho correlation tests showed that the relationship between the variants of these genes was not significant.

Table 1: Relationship between IRS1 and IRS2 gene polymorphisms

\begin{tabular}{lcccc}
\hline & & \multicolumn{2}{c}{ IRS1 gene } & \\
\cline { 3 - 4 } & & GA & GG & Total \\
\cline { 3 - 4 } IRS2 gene & AA & 2 & 26 & 28 \\
& GA & 3 & 71 & 74 \\
& GG & 6 & 48 & 54 \\
Total & 11 & 145 & 156 \\
\hline$X^{2}$ test $=2.37, p=0.305 ;$ & Spearman's rho correlation: \\
$r_{s}=-0.084, p=0.297$ &
\end{tabular}

\section{Influence of IRS genes on glycemic control}

Figures 1 and 2 show that there were no associations between the variants in IRS1 and IRS2 genes and glycemic control in patients with severe/acute phase hyperglycemia. 


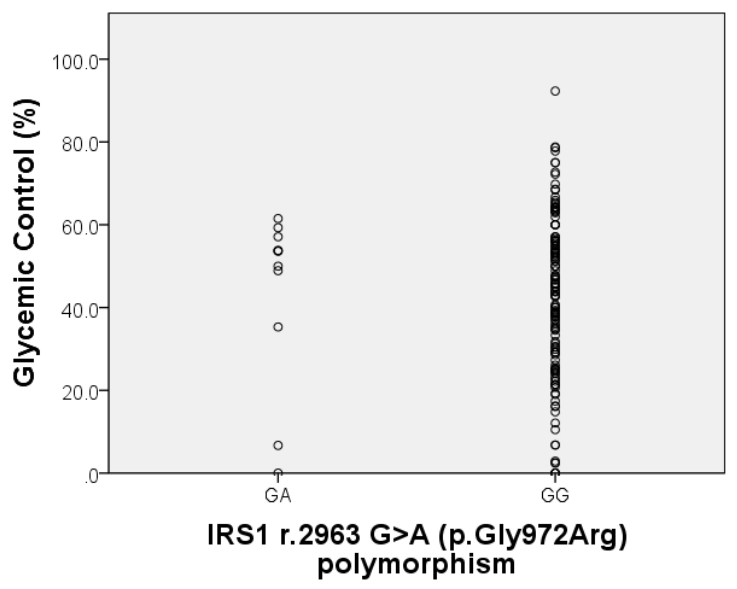

Figure 1: Comparison of IRS1 polymorphisms with glycemic control (\%). Spearman's rho correlation test: $\mathrm{R}^{2}=-0.023, p=0.771$

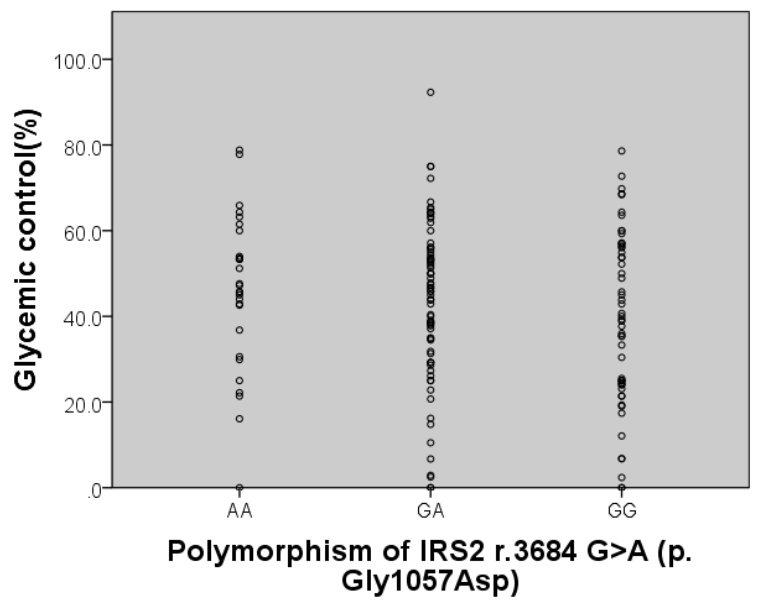

Figure 2: Comparison of IRS2 polymorphisms with glycemic control (\%). Spearman's rho correlation: $\mathrm{R}^{2}=$ $-0.160, p=0.046$

\section{DISCUSSION}

This study showed that there was no significant association between polymorphisms of genes IRS1 and IRS2 in patients with T2DM with severe or acute hyperglycemia. Although both IRS1 and IRS2 genes were included in the IRS system, their signaling specificity and distribution in tissues were different [4]. This result is supported by another study that found no significant interaction between the variants of these two genes [9]. Previous studies of the IRS1 gene were focused on the sensitivity and resistance to insulin in general patients with diabetes $[4,10,11]$, while studies of the IRS2 gene polymorphisms were focused on insulin resistance, obesity, endometriosis, and polycystic ovary syndrome [2,9]. However, none of the studies involved T2DM patients with severe/acute hyperglycemia.
This study found that neither IRS1 nor IRS2 gene polymorphisms correlated with glycemic control during severe hyperglycemia or acute phase. For IRS1 gene polymorphisms, the lack of a correlation with glycemic control may be due to the polymorphism having a direct relationship with insulin resistance and not glycemic control. The IRS2 gene polymorphisms may be associated with insulin resistance, but most studies cannot prove this theory $[12,13]$. However, polymorphisms in IRS1 and IRS2 genes might indirectly influence glycemic control. A study found that the Gly972Arg polymorphism in patients with T2DM causes weakness in the secretion of insulin, resulting in insulin deficiency and poor glycemic control [14]. The IRS1 gene polymorphism may predict the glycemic control of hyperglycemia during the acute phase if other factors, such as insulin resistance, were included in the analysis [15]. In other words, insulin resistance was seen as a subset of glycemic control. Thus, by studying other factors such as demographic and clinical factors that influence insulin resistance and glycemic control during severe hyperglycemia or acute phase directly and simultaneously, a clear relationship can be obtained [6]. Therefore, genetic factors alone might not be significant determinants for glycemic control in T2DM patients with severe/acute hyperglycemia. Other factors such as demographic and clinical factors may be considered in combination with genetic factors to improve glycemic control and quality of life for this group of patients.

\section{CONCLUSION}

IRS1 and IRS2 genetic factors may not be significant genetic determinants for glycemic control in T2DM patients in severe/acute phase hyperglycemia.

\section{Limitation of the study}

This study focused on a specific study population; hence, it might not be possible to extrapolate these results to other races or countries.

\section{ACKNOWLEDGEMENT}

The authors would like to thank the National University of Malaysia; University of Malaya, Malaysia; and the Ministry of Higher Education Malaysia for financial and technical support. 


\section{REFERENCES}

1. Huri HZ, Min YS, Pendek R: Episodes of hypoglycemia and hyperglycemia during the use of sliding scale insulin in hospitalized diabetes patients. Asian Biomed 2007; 1: 307-311.

2. American Diabetes Association: Standard of medical care in diabetes. Diabetes Care 2012; 35: S11-S63.

3. Marenzi G, De Metrio M, Rubino M, Lauri G, Cavallero A, Assanelli E, Grazi M, Moltrasio M, Marana I, Campodonico $\mathrm{J}$, et al: Acute hyperglycemia and contrast-induced nephropathy in primary percutaneous coronary intervention. Am Heart $J$ 2010; 160: 1170-1177.

4. Sesti G, Federici $M$, Hribal ML, Lauro $D$, Sbraccia $P$, Lauro R: Defects of the insulin receptor substrate (IRS) system in human metabolic disorders. FASEB $J$ 2001; 15: 2099-2111.

5. Huri, HZ, Makmor-Bakry M, Hashim R, Mustafa N, Wan Ngah WZ. A Prospective Cohort Study on IRS Gene Polymorphisms in Type 2 Diabetes Mellitus Patients during Severe/Acute Hyperglycemia Phase. Part 1: Association with Insulin Resistance. Tropical Journal of Pharmaceutical Research 2014; XX: X-X.

6. Huri HZ, Makmor-Bakry M, Hashim R, Mustafa N, Wan Ngah WZ. Optimisation of glycaemic control during episodes of severe/acute hyperglycaemia in patients with type 2 diabetes mellitus. Int J Clin Pharm 2012; 34: 863-870.

7. Hosking L, Lumsden S, Lewis K, Yeo A, McCarthy L, Bansal A, Riley J, Purvis I, Xu CF: Detection of genotyping errors by Hardy-Weinberg equilibrium testing. Eur J Hum Genet 2004; 12: 395-399.

8. Salanti G, Amountza G, Ntzani EE, loannidis JPA: HardyWeinberg equilibrium in genetic association studies: an empirical evaluation of reporting, deviations and power. Eur J Human Genet 2005; 13: 840-848.
9. Villuendas G, Botella-Carretero JI, Roldan B, Sancho J, Escobar-Morreale HF, San Millan JS: Polymorphisms in the insulin receptor substrate-1 (IRS1) gene and the insulin receptor substrate-2 (IRS2) gene influence glucose homeostasis and body mass index in women with polycystic ovary syndrome and nonhyperandrogenic controls. Hum Reprod 2005; 20: 3184-3191.

10. Imai $Y$, Fusco A, Suzuki Y, Lesniak M, D'Alfonso R, Sesti G, Bertoli A, Lauro R, Accili D, Taylor SI: Variant sequences of insulin receptor substrate-1 in patients with noninsulin-dependent diabetes mellitus. J Clin Endocrinol Metab 1994; 79: 1655-1658.

11. Hitman GA, Hawrami K, McCarthy MI, Viswanathan M, Snehalatha C, Ramachandran A, Tuomilehto J, Tuomilehto-Wolf E, Nissinen A, Pedersen O: Insulin receptor substrate-1 gene mutations in NIDDM; implications for the study of polygenic disease. Diabetologia 1995; 38: 481-486.

12. Fritsche A, Madaus A, Renn W, Tschritter O, Teigeler A, Weisser M, Maerker E, Machicao $F$, Häring $H$, Stumvoll M. The prevalent Gly1057Asp polymorphism in the insulin receptor substrate-2 gene is not associated with impaired insulin secretion. J Clin Endocrinol Metab 2001; 86: 4822-4825.

13. Ouederni TB, Sanchez-Corona J, Martinez SEF, Ben Maiz H, Skhiri HA, Abid HK, Benammar-Elgaaied A: The G1057D polymorphism of IRS-2 gene is not associated with type 2 diabetes and obese patients among ethnic groups in Tunisian population. Clin Biochem 2009; 42: 1169-1173.

14. Porzio O, Federici M, Hribal ML, Lauro D, Accili D, Lauro $R$, Borboni $P$, Sesti G: The Gly $\square$ Arg amino acid polymorphism in IRS-1 impairs insulin secretion in pancreatic beta cells. J Clin Invest 1999; 104: 357364. 